\title{
Hubungan Dukungan Sosial Teman Sebaya dengan Stres di STIKes Surya Global Yogyakarta
}

\section{Peer Social Support Relationship with Stress at STIKes Surya Global Yogyakarta}

\author{
Asri Setiowati ${ }^{*}$, Suib $^{2}$ \\ 1. Program Studi Keperawatan - STIKes Surya Global Yogyakarta - Indonesia \\ 2. Program Studi Keperawatan - STIKes Surya Global Yogyakarta - Indonesia \\ *Email Korespondensi: asrisetiawati07@gmail.com
}

\begin{abstract}
Abstrak
Latar Belakang: Seiring berjalannya waktu, mahasiswa akan mengalami stres. Dukungan sosial teman sebaya mampu menjadi cara dalam mengatasinya. Dengan adanya dukungan sosial yang diterima seperti perduli, bantuan emosional, instrumental dan informasi dapat mengurangi efek negatif stres yang dialami.

Tujuan: Mengetahui hubungan dukungan sosial teman sebaya dengan tingkat stres pada mahasiswa santri putri semester II Program Studi Keperawatan di STIKes Surya Global Yogyakarta.

Metode: Metode menggunakan non-eksperimen dengan penelitian deskriptif korelasi dan menggunakan rancangan cross sectional. Teknik pengambilan sampel menggunakan systematic random sampling dengan jumlah responden sebanyak 51 mahasiswa santri putri. Analisis data menggunakan uji Kendall Tau.

Hasil: Hasil menunjukkan responden dengan dukungan sosial teman sebaya yang baik dengan tingkat stres ringan sebanyak 37 responden $(82,2 \%)$. Analisis data Kendall Tau membuktikan signifikansi $\mathrm{p}=0,003$ yang berarti bahwa $p=<0,05$. Dan untuk nilai koefisien korelasi $r=-0,629$.

Kesimpulan: Berhubungan signifikan dukungan sosial teman sebaya dengan tingkat stres pada mahasiswa santri putri semester II Program Studi Keperawatan di STIKes Surya Global Yogyakarta.
\end{abstract}

Kata Kunci: Dukungan sosial teman sebaya; Mahasiswa; Stres

\begin{abstract}
Background: Students in their development are prone to experiencing stress due to changes they experience. Peer social support can be a support system that can help the development process. The social support received in the form of attention, emotional assistance, instrumental support, and information provided can reduce the negative effect of stress experienced.

Objective: To determine relationship peer social support and the level of stress in female students of the second semester Nursing Program at STIKes Surya Global Yogyakarta.

Method: This research is a non-experimental study with a correlation descriptive research design and using a cross-sectional design. The sampling technique used systematic random sampling with a total of 51 female students. The method of analysis used the Kendall Tau test.

Result: The study showed that 37 respondents (82,2\%) had good peer social support with a mild stress level. Kendall Tau analysis shows significance $=0,003$, which means that $p<0,05$. While the value of the correlation coefficient $r=-0,629$.

Conclusion: There is a significant relationship between peer social support and stress level in female students of semester II the Nursing Program at STIKes Surya Global Yogyakarta.
\end{abstract}

Keyword: Peer social support; Stress; Students. 


\section{PENDAHULUAN}

Menurut World Health Organization (WHO), jumlah stres sangat tinggi hampir 350 juta penduduk dunia mengalami stres. Stress lebih sering terjadi pada wanita $(54,62 \%)$ dibandingkan pada pria $(45,38 \%)$ dan meningkat tiap tahun (10). Data mahasiswa di dunia yang mengalami stres berkisar 38-71\%, sementara di Asia 39,6-61,3\%, di Indonesia didapatkan 36,7-71,6\% mahasiswa mengalami stres (1). Sebesar 6,0\% masyarakat Indonesia yang berumur lebih dari 15 tahun mengalami gangguan mental emosional berupa stres, kecemasan, dan depresi (1).

Stres adalah masalah yang dialami dalam kehidupan manusia, stres merupakan hal wajar yang dialami semua orang. Hal ini karena stres sudah menjadi hal yang sering dialami dan sudah menjadi bagian hidup dan dapat dialami siapa saja. Stres juga reaksi dari tubuh terhadap lingkungan yang dapat melindungi diri individu juga merupakan bagian dari sistem pertahanan yang membuat kita dapat bertahan hidup (8).

Dukungan sosial (social support) merupakan perlakuan yang diberikan seseorang terhadap orang yang akrab pada kehidupan sehari-harinya, memberikan keuntungan dan berpengaruh untuk penerimanya. Orang yang mendapatkan dukungan sosial baik akan merasa senang karena diperhatikan, dan mendapatkan kasih sayang (2). Pendapat lain menyatakan bahwa dukungan sosial adalah seseorang yang selalu ada, peduli, dapat diandalkan dan sayang dengan kita.

Penelitian sebelumnya menunjukkan ada hubungan signifikan antara dukungan sosial dengan stres akademik pada siswa boarding school. Sebagian besar responden memiliki hubungan dukungan sosial baik dan sebagian besar responden memiliki stres yang rendah. Hal ini menunjukkan semakin tinggi dukungan sosial maka rendah pula stres akademik yang dirasakan, dan sebaliknya jika semakin rendah dukungan sosial maka stres akademik yang dialami akan tinggi (3).

Dukungan sosial berkorelasi negatif dengan stres pada mahasiswa yang sedang menyusun skripsi di Universitas Muhammadiyah Malang. Hal ini menunjukkan bahwa semakin tinggi dukungan sosial dari teman sebaya maka tingkat stres pada mahasiswa yang sedang mengerjakan skripsi semakin turun. Dukungan sosial teman sebaya terhadap stres pengaruhnya sebesar $6.7 \%$ sedangkan sisanya yaitu stres yang dikarenakan adanya faktor lain diluar penelitian (9).

Peneliti lainnya menunjukkan bahwa kedekatan teman sebaya berkorelasi negatif dengan stres akademik yaitu nilai korelasi sebesar $r=-0,402$ dan $p<0,05$. Hal ini menunjukkan nilai koefisien negatif yang artinya semakin tinggi kedekatan teman sebaya maka stres akademiknya yang dialami menjadi rendah, dan juga sebaliknya jika kedekatan teman sebaya rendah maka stres akademiknya yang dialami menjadi tinggi (10).

Berdasarkan wawancara yang dilakukan kepada 10 para mahasiswa santri, enam diantaranya memilih bercerita dengan teman sebayanya dan mendapatkan dukungan dari teman sebayanya mengenai kehidupan yang dijalaninya selama di pondok pesantren. Namun, ada juga mahasiswa santri yang acuh mengenai kehidupan yang ada di pondok pesantren dan merasa mampu untuk menyelesaikan masalah yang ada sehingga tidak merasa perlu dukungan dari teman sebaya. Mahasiswa santri juga mengatakan belum pernah tinggal di lingkungan pondok pesantren sehingga merasa tertekan dengan peraturan-peraturan yang ada dan juga apa yang mereka pikirkan tidak sesuai dengan harapan mereka selama tinggal di pondok pesantren sehingga harus banyak beradaptasi dengan lingkungan yang baru. Berdasarkan permasalahan tersebut, peneliti bermaksud melakukan penelitian mengenai hubungan antara dukungan sosial teman sebaya dengan tingkat stres pada mahasiswa santri putri semester II program studi keperawatan di STIKes Surya Global Yogyakarta. 


\section{METODE}

Penelitian ini merupakan non-eksperimen dan termasuk penelitian deskriptif korelasi yang menggunakan pendekatan cross sectional. Metode analisis data menggunakan Kendall Tau. Pengambilan sampel menggunakan systematic random sampling dengan 51 responden mahasiswa santri putri semester II program studi keperawatan di STIKes Surya Global Yogyakarta. Pengambilan dengan systematic random sampling yaitu dengan melakukan seleksi acak secara sistematis dengan menggunakan rumus dari Notoadmojo (2018), dimana pengambilan sampel diperoleh dari kelipatan 2 dari tiap kelas yang ada. Pengambilan data menggunakan kuesioner. Adapun kuesioner yang digunakan diadopsi dari penelitian Baroroh (11), dan untuk kuesioner tingkat stres adalah kuesioner DASS 42 yang mengambil item tentang stres yang diadopsi dari penelitian Nursalam (12).

Analisis data yang digunakan adalah univariat dan bivariat. Pada penelitian ini menggunakan uji korelasi Kendall Tau dikarenakan skala data yang ada berupa skala data ordinal dan ordinal dan juga menggunakan analisis data Kendall Tau untuk mengetahui hubungan dari kedua variabel yang diteliti yaitu dukungan sosial teman sebaya dan tingkat stres.

Ethical Clearence (EC) dilakukan di Komisi Etik Penelitian Kesehatan (KEPK) STIKes Surya Global Yogyakarta bernomor 1.27/KEPK/SG/III/2020. Responden bersedia dan siap untuk diperoleh data dan mengikuti penelitian yang dilakukan.

\section{HASIL}

Dilihat dari tabel 1 berdasarkan karakteristik usia mahasiswa santri putri menunjukkan bahwa mayoritas responden berusia 17-18 tahun sebanyak 56,9\%.

Tabel 1. Karakteristik Responden berdasarkan Usia Mahasiswa Santri Putri Semester II di STIKes Surya Global Yogyakarta

\begin{tabular}{ccc}
\hline Usia & Jumlah $(\mathrm{n})$ & Presentase $(\%)$ \\
\hline $17-18$ tahun & 29 & $56,9 \%$ \\
$19-20$ tahun & 22 & $43,1 \%$ \\
\hline Total & 51 & $100 \%$ \\
\hline
\end{tabular}

Berdasarkan hasil uji pada tabel 2 rata-rata mahasiswa santri putri di STIKes Surya Global Yogyakarta menunjukkan bahwa 88,2\% responden mendapatkan dukungan sosial dari teman sebaya dengan baik.

Tabel 2. Dukungan Sosial Teman Sebaya Mahasiswa Santri Putri Semester II di STIKes Surya Global Yogyakarta

\begin{tabular}{lcc}
\hline \multicolumn{1}{c}{ Dukungan Sosial Teman Sebaya } & Jumlah $(\mathrm{n})$ & Persentase $(\%)$ \\
\hline Kurang baik & 2 & $3,9 \%$ \\
Cukup baik & 4 & $7,8 \%$ \\
Baik & 45 & $88,2 \%$ \\
\hline Total & 51 & $100 \%$ \\
\hline
\end{tabular}

Dilihat dari tabel 3 terdapat $21,6 \%$ responden mengalami stres sedang dan 5,9\% responden mengalami stress berat.

Tabel 3. Tingkat Stres Mahasiswa Santri Putri Semester II di STIKes Surya Global Yogyakarta

\begin{tabular}{|c|c|c|}
\hline Tingkat Stres & Jumlah (n) & Persentase (\%) \\
\hline Berat & 3 & $5,9 \%$ \\
\hline Sedang & 11 & $21,6 \%$ \\
\hline Ringan & 37 & $72,5 \%$ \\
\hline Total & 51 & $100 \%$ \\
\hline
\end{tabular}


Tabel 4 Analisis Tabulasi Silang Dukungan Sosial Teman Sebaya dengan Tingkat Stres pada Mahasiswa Santri Putri Semester II Program Studi Keperawatan di STIKes Surya Global Yogyakarta

\begin{tabular}{lcccccccc}
\hline \multirow{2}{*}{$\begin{array}{c}\text { Dukungan sosial } \\
\text { teman sebaya }\end{array}$} & \multicolumn{9}{c}{ Tingkat Stres } & \multicolumn{2}{c}{ Total } \\
\cline { 2 - 9 } & $\mathrm{n}$ & $\%$ & $\mathrm{n}$ & $\%$ & $\mathrm{n}$ & $\%$ & $\mathrm{n}$ & $\%$ \\
\hline Kurang & 0 & 0,0 & 1 & 50,0 & 1 & 50,0 & 2 & 100,0 \\
Cukup & 0 & 0,0 & 2 & 50,0 & 2 & 50,0 & 4 & 100,0 \\
Baik & 37 & 82,2 & 8 & 17,8 & 0 & 0,0 & 45 & 100,0 \\
\hline Total & 37 & 21,6 & 11 & 5,9 & 3 & 5,9 & 51 & 100,0 \\
\hline
\end{tabular}

Berdasarkan tabel 4 sebagian besar responden memiliki dukungan sosial teman sebaya baik yaitu sebesar $82,2 \%$ responden,dengan tingkat stres ringan sebesar 17,8\% responden.

Tabel 5 Analisis Bivariat Korelasi Kendall Tau Dukungan Sosial Teman Sebaya dengan Tingkat Stres pada Mahasiswa Santri Putri Semester II di STIKes Surya Global Yogyakarta

\begin{tabular}{lcc}
\hline \multicolumn{1}{c}{ Variabel } & $\begin{array}{c}\text { Nilai koefisiensi } \\
\text { Korelasi }\end{array}$ & Nilai Sig \\
\hline Dukungan Sosial Teman Sebaya & $-0,629$ & 0,003 \\
\hline Tingkat Stres & & \\
\hline
\end{tabular}

Dari tabel 5 menunjukkan hasil uji statistik menggunakan korelasi Kendall Tau diperoleh nilai $p=0,003$ yang berarti $\rho<0,05$ dan untuk nilai koefisien korelasinya $p=-0,629$ ini berarti bahwa Ha diterima dan Ho ditolak maksudnya terdapat hubungan negatif yang signifikan antara Dukungan Sosial Teman Sebaya dengan Tingkat Stres pada Mahasiswa Santri Putri Semester II di STIKes Surya Global Yogyakarta.

\section{PEMBAHASAN}

Sebagian besar mahasiswa santri putri semester II di STIKes Surya Global Yogyakarta, memiliki dukungan sosial teman sebaya yang baik. Hal ini menunjukkan bahwa dengan adanya dukungan sosial teman sebaya dapat menjadi faktor untuk mengurangi tingkat stres pada mahasiswa santri putri semester II di STIKes Surya Global Yogyakarta.

Sejalan dengan penelitian sebelumnya bahwa ada hubungan yang signifikan antara dukungan sosial teman sebaya dengan prokrastinasi menghafal alqur'an. Santri dengan dukungan sosial teman sebaya yang tinggi mampu mengatasi gejolak yang timbul selama proses menghafal alqur'an, contohnya stres yang dialami tiap orang mampu berpengaruh positif dan negatif. Pengaruh positif maksudnya membantu orang untuk semangat dan mendapatkan pengalaman yang baru, sedangkan pengaruh negatif yaitu membuat khawatir, gelisah, tidak percaya diri (4).

Berdasarkan hasil penelitian membuktikan bahwa sebagian besar mahasiswa santri putri semester II memiliki tingkat stres ringan. Penelitian sebelumnya menunjukkan bahwa ratarata tingkat stress responden adalah stress tingkat sedang sebanyak $65,4 \%$ responden. Hal yang diukur untuk tingat stress mahasiswa pada penelitian ini ada 8 indikator yaitu perasaan ansietas, emosional negatif, ketegangan, ketakutan, gangguan tidur, gangguan kecerdasan, perasaan depresi, dan gejala somatik (5).

Selain itu, penelitian lainnya didapatkan bahwa 62,97\% responden berjenis kelamin perempuan dan sisanya berjenis kelamin laki-laki. Usia responden dalam rentang usia remaja dan dewasa awal. Distribusi tingkat stres mahasiswa STIKes Yogyakarta saat menyusun 
skripsi masuk dalam kategori normal sebanyak 59,3\%, kategori ringan sebesar $18,5 \%$ dan selebihnya dalam kategori sedang sampai dengan sangat berat (6).

Berdasarkan hasil penelitian menunjukkan bahwa terdapat hubungan dengan korelasi negatif yang signifikan antara dukungan sosial teman sebaya dengan tingkat stres pada mahasiswa santri putri semester II di STIKes Surya Global Yogyakarta, dengan nilai koefisiensi $\mathrm{r}=-0,629$ dan $p=0,003$. Hal ini menunjukkan bahwa semakin baik dukungan sosial teman sebaya yang diberikan maka tingkat stres yang akan dialami mahasiswa santri putri semakin rendah, begitupun sebaliknya semakin rendah dukungan sosial teman sebaya maka semakin tinggi tingkat stres yang akan dialami.

Korelasi negatif yang diperoleh sesuai dengan penelitian sebelumnya bahwa dukungan sosial berkorelasi negatif dengan stres akademik pada siswa SMA boarding school dengan nilai $\mathrm{r}=-0,380$ dan $p=0,000 \quad(\mathrm{p}<0,05)$. Penelitian lain yang serupa menyatakan bahwa kelekatan teman sebaya berkorelasi tidak searah (negatif) dengan stres akademik pada mahasiswa teknik perencanaan wilayah dan kota Universitas Diponegoro Semarang. Nilai koefisien korelasi yang diperoleh sebesar $r=-0,402$ dan $p<0,05$. Hal ini berarti semakin baik dukungan sosial teman sebaya maka semakin rendah tingkat stres yang akan dialami dan begitu juga sebaliknya (10).

Dilihat dari dukungan sosial yang di berikan kepada mahasiswa santri putri semester II di STIKes Surya Global Yogyakarta, mereka lebih banyak mendapat dukungan dari teman seusianya. Pendapat lain menyatakan bahwa dukungan sosial merupakan kenyamanan secara fisik dan psikologis yang diberikan oleh orang lain (teman atau anggota keluarga) (9). Dukungan sosial ini dapat diraih dari orang yang berada di sekitar kita karena saat mendapatkan dukungan sosial dari orang lain atau teman sebaya mahasiswa santri putri semester II merasa mudah dalam menyelesaikan masalah yang ada dan juga mampu mengurangi stres yang dialami.

Tingkat stres pada mahasiswa santri putri semester II di STIKes Surya Global Yogyakarta sebagian besar pada kategori stres ringan dengan 72,5\% responden, artinya mahasiswa santri putri semester II mengalami stres dalam menghadapi permasalahan maupun tuntutan di kampus ataupun di asrama. Stres merupakan suatu keadaan yang timbul akibat gejala atau peristiwa dan keadaan dimana merasa sangat terancam sehingga menimbulkan reaksi dari dalam tubuh (18). Begitu juga kondisi stres pada mahasiswa santri putri semester II di STIKes Surya Global Yogyakarta diakibatkan karena banyaknya tuntutan tugas kuliah dan juga padatnya kegiatan diasrama dan aturan-aturan yang harus mereka taati.

Penelitian serupa membuktikan bahwa terdapat hubungan antara dukungan sosial teman sebaya dengan stres pada lansia di unit pelaksana teknis pelayanan sosial Tresna Werdha kabupaten Jember dengan nilai $p=0,001$, dan memiliki nilai korelasi variabel dukungan sosial teman sebaya dengan stres pada lansia yaitu $r=-0,446$ yang menunjukkan kekuatan korelasi termasuk dalam kategori sedang (7).

\section{SIMPULAN}

Dukungan sosial teman sebaya pada mahasiswa santri putri semester II dalam kategori baik dengan jumlah $88,2 \%$ responden, tingkat stres pada mahasiswa santri putri semester II dalam kategori ringan dengan jumlah $72,55 \%$ responden dan signifikan antara dukungan sosial teman sebaya dengan tingkat stres pada mahasiswa santri putri semester II Program Studi Keperawatan di STIKes Surya Global Yogyakarta dengan nilai koefisien korelasi Kendall Tau $-0,629$ dan nilai signifikannya 0,000 . 


\section{SARAN}

Bagi mahasiswa santri putri, penelitian ini dapat menambah pengetahuan mahasiswa mengenai pentingnya hubungan dukungan sosial teman sebaya sehingga mahasiswa santri dapat mengatasi masalah-masalah yang ada guna mengurangi tingkat stres yang dialami mahasiswa santri. Bagi peneliti selanjutnya diharapkan penelitian ini dapat menjadi sumber referensi dan bahan pertimbangan, khususnya penelitian yang mengambil tema yang serupa hubungan dukungan sosial teman sebaya dengan tingkat stres.

\section{UCAPAN TERIMAKASIH}

Peneliti mengucapkan terimakasih kepada mahasiswa santri putri semester II Program Studi Keperawatan di STIKes Surya Global Yogyakarta selaku responden yang sudah membantu dalam penelitian ini.

\section{DAFTAR PUSTAKA}

1. Linasari FS. 2017. Hubungan Tipe Kepribadian dengan Tingkat Stres Pada Mahasiswa Baru Fakultas Kedokteran Universitas Andalas Tahun 2016. J Andalas. 2017;(2010):15.

2. Alfajar.2019. Hubungan Dukungan Sosial Teman Sebaya dengan Optimismes Santri Pondok Pesantren. Fakultas Psikologi. Skripsi. Riau. Universitas Islam Negeri Sultan Syarif Kasim.

3. Hidayah, Miftahul. 2018. Hubungan Dukungan Teman Sebaya dan Stres Akademik pada Siswa SMA Boarding School. Skripsi. Program Studi Psikologi. Fakultas Psikologi dan Sosial Budaya. Yogyakarta. Universitas Islam Indonesia.

4. Wiyarti HA, Setyawan I. Prokrastinasi Menghafal Al- Qur' An pada Santri di Pondok Pesantren Modern Islam Assalaam Surakarta. J Empati. 2017;6(Nomor 4):33-6.

5. Ulum MC. 2018. Stress dalam Penyusunan Skripsi Pada Mahasiswa Semsester VIII S1 Keperawatan. Stikes Program Studi S1 Ilmu Keperawatan Sekolah Tinggi Ilmu Kesehatan "Insan Cendekia Medika " Jombang.

6. Rosyad YS. 2019. Tingkat Stres Mahasiswa Sekolah Tinggi Ilmu Kesehatan Yogyakarta dalam Mengerjakan Skripsi Tahun Akademik 2018/2019. Cahaya Pendidik. 2019;5(1):56-64.

7. Kemenkes RI. 2013. Riset Kesehatan Dasar. Jakarta. Kementrian Kesehatan RI.

8. Utami, D R. 2016. Pengaruh Humor Terhadap Penurunan Tingkat Stres Mahasiswa Psikologi yang Mengerjakan Skripsi di Universitas Negeri Semarang. Semarang. Jurusan Psikologi, Fakultas Ilmu Pendidikan, Universitas Negeri Semarang.

9. Rohmah, Qonita. 2017. Pengaruh Dukungan Sosial Teman Sebaya Terhadap Stres pada Mahasiswa yang Mengerjakan Skripsi di Universitas Muhammadiyah Malang. Malang. Fakultas Psikologi, Universitas Muhammadiyah Malang.

10. Purwati, Mirna. 2018. Hubungan antara Kelekatan pada Teman Sebaya dengan Stres Akademik pada Mahasiwa Teknik Perencanaan Wilayah dan Kota Universitas Diponegoro Semarang. Fakultas Psikologi. Jurnal Empati Vol 7 No 2 Hal 28-19. Semarang. Universitas Diponegoro.

11. Baroroh, F. 2017. Hubungan antara dukungan sosial teman sebaya dengan stress related growth pada santri pondok pesantren STIKes Surya Global Yogyakarta. Program Studi Ilmu Keperawatan. Skripsi. Yogyakarta. STIKes Surya Global.

12. Nursalam. 2017. Metodologi Penelitian Ilmu Keperawatan. Jakarta Selatan. Salemba Medika 